\title{
Digital competence as arequirement for development of innovative educational environment at university
}

\author{
Irina I. Lysova, Olga A. Vitokhina, Olga V. Volkova \\ Belgorod University of Cooperation, Economics \& Law \\ 116 a Sadovaya St, Belgorod, 308023, Russia \\ E-mail: liriv@yandex.ru; violga7@mail.ru; wolga_bel@mail.ru
}

\begin{abstract}
The study examines innovative educational technologies for their potential impact on and use in teaching, learning, and creative inquiry within the higher education environment. The analysis of the problem connected with creating (transforming) the educational environment in the context of digitalization showed that this multifaceted task requires further study. The aim of the work is to review and assess the implementation of digital technologies in the university educational environment. The urgency of using digital technologies in the teaching-learning process has been substantiated; the importance of the digital competence formation for all educational process participants has been shown; the significance of filling the curricular with online products has been emphasized; the need to combine traditional educational methods with innovative technologies has been confirmed by the example of foreign language teaching. A systematic approach, desk research and expert assessment methods were used. The new ways of forming digital competence based on the use of open online resources are revealed; original ways of convergence of traditional and innovative educational environment are presented. The authors attempted to develop a methodological approach towards connecting learning inside/outside the classrooms through the digital cloud and estimate the impact of the digital revolution on the learners and teachers' profile. The research results can be used by teachers perceiving digital competence as a new tool for converting learning environment into a comfort zone.
\end{abstract}

Key words: learning environment, lifelong education, e-learning, information and communication technologies, feedback.

For citation: Lysova I. I., Vitokhina O. A., Volkova O. V. 2020. Digital competence as a requirement for development of innovative educational environment at university. Issues in Journalism, Education, Linguistics, 39 (3): 408-418 (in English). DOI 10.18413/2712-7451-2020-39-3-408-418

\section{Цифровая компетентность как условие развития инновационной образовательной среды в вузе}

\author{
Лысова И.И., Витохина О.А., Волкова О.В. \\ Белгородский университет кооперации, экономики и права \\ Россия, 308023, г. Белгород, ул. Садовая, д. 116а \\ E-mail: liriv@yandex.ru; violga7@mail.ru; wolga_bel@mail.ru
}

\begin{abstract}
Аннотация. Создание инновационной образовательной среды в вузе способно качественно изменить процесс подготовки специалистов, обладающих цифровой компетентностью. Анализ проведенных исследований по проблеме создания (преобразования) образовательной среды вуза в условиях цифровизации показал, что данная многоаспектная задача требует дальнейшего изучения. Целью работы является рассмотрение и оценка внедрения цифровых технологий в образовательную среду университета. Обоснована актуальность использования цифровых технологий в образовательном процессе высшей школы; показана важность формирования цифровой компетентности у всех участников образовательного процесса; акцентирована значимость наполнения содержания учебных дисциплин онлайн-продуктами: подтверждена
\end{abstract}


необходимость сочетания традиционных методов с инновационными технологиями в учебном процессе на примере обучения иностранному языку. Использован системный подход, кабинетное исследование и методы экспертных оценок. Выявлены оригинальные пути формирования цифровой компетентности на основе использования открытых онлайн ресурсов; представлены новые способы сближения традиционной и инновационной образовательной среды; показано, каким образом цифровая компетенция может повлиять на динамику урока преподавателя иностранного языка, изменяя учебную аудиторию с помощью доступных технологий и ресурсов. Результаты исследования могут быть использованы педагогами, заинтересованными в формировании образовательной среды для реализации инноваций.

Ключевые слова: цифровая компетентность, среда обучения, непрерывное образование, электронное обучение, информационные и коммуникационные технологии, обратная связь.

Для цитирования: Лысова И. И., Витохина О. А., Волкова О. В. 2020. Цифровая компетентность как условие развития инновационной образовательной среды в вузе. Вопросы журналистики, педагогики, языкознания, 39 (3): 408-418. DOI 10.18413/2712-7451-2020-39-3-408-418

\section{Introduction}

Recommendation of the European Parliament and the Council of 18 December 2006 on key competences for lifelong learning supported the development of competence-oriented teaching and learning as well as related curricula reforms. Competence-oriented educational approaches and curricula focus not only on the outcomes of a learning process but also on the application of that learning in new or different contexts. Competences include more than knowledge and understanding and take into account the ability to apply them when performing a task. Competence-oriented education is regarded as advantageous in a time when digital orientation of our societies is developing at an immense speed and when the skills required need to be transferred to and developed in many different societal contexts, including the ones unforeseen in the future.

Today we witness fortified collaboration between training and learning sceneries at all levels as well as strengthened outfits, means and directions in education and employment to back public in managing their lifelong learning pathway.

Digital age is a new stage in the development of humankind associated with the construction of a global knowledge-based information or digital society. Today it is safe to say that humanity has entered a qualitatively new stage in its development related to the construction of a global digital society. This new era of human development corresponds to the concept of creating a Global Information Network or Global Digital Society, which has become a common platform for interaction of all subjects of the modern world to solve the problem of implementing a new era, which is based on such basic concepts as: information, data, knowledge and communication.

Digital competence definition concerns "the basic skill or ability to use a computer confidently, safely and effectively, including: the ability to use office software such as word processors, email and presentation software, the ability to create and edit images, audio and video, and the ability to use a web browser and Internet search engines" [Royal Society, 2012, c.17]. The stated skills are almost obligatory in the global digital society is a lifelong perspective and, in fact, a new cultural and historical context for the humanity development under the conditions of the forthcoming fourth industrial revolution (PR4.0), which involves transformation of production, economy and the social sphere through the widespread use of information, communication, digital and hybrid technologies [Kozhevnikova, 2011].Technological changes concern all the elements of the social sphere including education. Transformation of services focuses on creating new educational products and converting existing ones to digital. This usually means converting traditional stand-alone lectures into a video format, creating digital content, including multime- 
dia. In addition, it includes the provision of digital means of communication. To implement the stated task all the actors of the education process should possess digital competence.

Digital competence is currently considered to be a vital requirement for life and occupation, or rather a survival skill. It serves as a cornerstone, which allows mastering other key competences (e.g. communicative, reasoning, critical thinking, knowledge widening, cultural awareness). It is also important for ensuring citizens' active participation in social life [Rozdolskaya i dr., 2017].

Digital skills should be inserted both in the instruction process in a whole and in every subject in particular. It is reasonable to start the process of digital learning as early as it could be and for higher education, we estimate it as an obligatory one. Students are to learn to use digital instruments critically and creatively [Isaev, Eroshenkova, 2011].

As education is at least a two-side process, teachers need to constantly master their digital competence in order to manage and support instruction [Rastova i dr., 2006]. Besides, today digital competence is a general prerequisite for all the population for acting, working and learning in the information society. We can claim that digital competence is now reckoned as a great strategic significance and helps in many aspects of our life, i.e. public, healthiness, trade and industry, social life, ethnic identity, etc. [Tarasova, Altonayan, 2017].

\section{Main Body}

Digital competence has many different aspects and features, embracing a lot of areas and fields of knowledge and it spreads and widens quickly in parallel with appearance of new technologies. Being digitally competent means to be able to follow its five crucial areas, which were identified and summarized as follows [The Digital Competence Framework 2.0, 2019]:

1. Information: to identify, locate, retrieve, store, organize and analyze digital information, judging its relevance and purpose. The information capacity includes searching, evaluating, filtering and saving information.

2. Communication: to communicate in digital environments, share resources through online tools, link with others and collaborate through digital tools, interact with and participate in communities and networks, possess cross-cultural awareness. Successful communication embraces networking by means of technologies; material and content distribution; digital identity and netiquette. It is a technical competence. It concerns dealing with various software, ability to code. At the same time creative results assume partnership, revealed in the communication area.

3. Content-creation: to create and edit new content (from word processing to images and video); to integrate and re-elaborate previous knowledge and content; to produce creative expressions, media outputs and programming; to deal with and apply intellectual property rights and licenses; to work on content-creation; to possess competences in copyright and licenses; to elaborate the content; to produce and distribute multimedia products and programs matching with different software.

4. Safety: personal protection, data protection, digital identity protection, security measures, safe and sustainable use. Safety is that very area, which is closely connected with different competences, for example, digital identity and netiquette. Nowadays it is crucial for people to know about threats existing on-line.

5. Problem-solving: to identify digital needs and resources; to make informed decisions on most appropriate digital tools; to use technologies for solving technical problems; to maintain students interest and participation.

For any educational institution and its actors today it is vitally important to acquire ability to identify and eliminate digital competence gaps. Digital reality helps create learning environment with the focus on particularly innovative, influential and actual architecture. To understand the main trends of learning environments for the 21st century we analyzed actual research reviews. Most of them provide the following flow-through principles [Bazanova, 2012]: 
- recognize the learners as core participants of the education process, inspire their vigorous engagement, and develop their understanding of the importance of being active learners;

- be founded on the social nature of learning and actively encourage both group work and well-organized co-operative learning;

- be acutely sensitive to the individual differences among the learners, including their prior knowledge;

- use devise programs that demand hard work and challenge from all without excessive overloading;

- operate with clarity of expectations and deploy assessment strategies consistent with these expectations; there should be strong emphasis on formative feedback to support learning;

- strongly promote "horizontal connectedness" across areas of knowledge and subjects as well as to the community and the wider world [Benavides et al., 2010; Neumann, 2018).

The strength and significance of each principle is vital in close cohesion with the others. All together they provide a proper framework for creating an effective learning environment. It is vitally important to understand that all these principles (embracing students' activity, cooperative learning, professionals' competence, well-organized working process, effective feedback, horizontal connectedness) can be augmented considerably by means of IT technologies.

Digital or information and communication technologies (ICT) initiated a lot of changes and modifications occurring in everyday life as ICT penetrated into all spheres of routine work and facilitated to blurring boundaries between virtual and traditional environment [Irkhina i dr., 2012]. The computer-generated surroundings therefore spread and enhance the grasp of learners in their training - concerning communication and relationships development with their group mates, instructors and gaining access to enormous and rich knowledge bases [Kolos, Kuzminova, 2016]. ICT influence is essential for education process. Innovative methods of teaching and learning are being widely introduced; new sources of instructive information have appeared and are actual for teachers and students. The lifelong learningconcept, worked out by European Parliament, has become widely spread. It includes eight competences: literacy competence; languages' competence; science, technological, engineering and mathematical competence; digital competence; personal, social and learning competence; civic competence; entrepreneurship competence; and cultural awareness and expression competence [Recommendation of the European Parliament, 2006]. Lifelong Learning ideas should be anchored in the public mind from early childhood education and reinforced in adult education, reproducing the necessity to upkeep competence development in a sustainable lifelong learning outlook. In the frames of knowledge society, they are in great demand being closely connected with ICT, which serve as a means for optimal social inclusion, excellence of life and effectiveness in work, market and economic development. Implementation of ICT in the education process can be seen as one of the crucial constituents in teaching and learning policies and it is turning into an object of scientific investigation. The concept of digital competence is becoming a priority in actions and initiatives of every higher educational establishment.

This sustainable education philosophy initiates inclusive and fair quality education and lifelong learning opportunities for every person. For being competitive and appropriate it is actual to develop new skills, be engaged in self-taught study, acquire skills in a new sport or activity, learn to use a new technology, gain new knowledge. Personal self-actualization and satisfaction can be achieved both by chasing personal interests and desires and careering professional goals as humans have a naturally occurring motivation to discover, study and improve their own quality of life and inspire a sense of self-esteem [Lysova i dr., 2016].

Lifelong learning, which is a form of self-initiated training oriented at personal development, emphasizes the following features:

- foster students of all ages and in all forms of education, including non-formal and formal ones, in developing key competences for lifelong learning; 
- up-date programs to present and prospect demands to be certain that the public can acquire and master the competences they need;

- work out steps to encourage competence-oriented instruction in lifelong learning perspective, that is creation of innovative learning environment, backing for professors and other educational staff; evaluation of competence development.

E-learning is well fitted to satisfy these features. Authentic learning experience aimed at mastering an education program by electronic means is provided by e-learning. It includes webbased learning, virtual laboratories, digital cooperation and distribution of information via the Internet. It can go along with face-to-face learning with a lecturer and in mixed learning. Nowadaysformal education system is under growing burden connected with answering and adjusting to prompt technological development as well as to attendant alterations appearing in the environment we act and live. There is an urgent need to enrich learning process by applying new pedagogical approaches and IT technologies, and thus make formal education more engaging and actual [Kozhevnikova, 2014].

Under the present situation, teachers with student-centered views are inclined to realize student-oriented curricula even if there exist technical, managerial or assessment barriers. Instructors' own opinions and outlooks concerning the appropriateness of technology for students' learning are understood as the ground for their success. Furthermore, inside factors (e.g. desire for using technology, rational problem-solving, priority-driven mentality) and maintenance from other actors (managers, officers, and learning networkers) are crucial for determining teachers' practices. The strongest barriers on the way to using technology are wrong attitudes and views on technology and lecturers' insufficient levels of knowledge. It is vitally important to understand that modern students not only chose but create the content. Along with their teachers they can become experts on specific content areas. All the available learning resources should be used flexibly to satisfy individual student educational needs [Boldova, 2012].

In the present study we consider some on-line opportunities for learning languages. They include:

- selecting digital resources understanding applicable copyright and accessibility requirements;

- organizing, sharing and publishing digital resources respecting the rules of copyright;

- creating and modifying digital resources considering the specific learning objective, content, pedagogical approach and learner group.

Learning languages and being able to communicate in more than one language remains one of the key competences for lifelong learning. The focus of the Languages Competence is on improving the development of linguistic competences and stressing the importance of learning languages as a tool for communication within multilingual societies and work environments.

Among the stable and experienced providers of e-learning language materials are the British Council, the British Study Centers, BBC, which help meet language training needs. There are also online learning communities where anyone can learn different subjects created by professionals free of charge. For example, Memrise [Mem Rise, 2010-2020]. It is the exact combination of science and fun. It is a good enhancement in the learning process both for teachers tracking the progress of their students and the students hoping to better retain what they learn. It is designed for learning vocabulary, grammar and interesting facts. Memrise is grounded on some significant scientific findings about how we learn. It includes the system of mnemonics, memory aids, mind maps, spaced repetition, crowdsourcing that encourage human brain to work better by engaging imagination. As a result, it facilitates establishment of tougher and more long-lasting memories, allows to keep information in the human mind; to convert data into a form that the brain can keep in a better in comparison with its original form [Davidenko, 2013].

One more useful site for increasing students' awareness of their learning a foreign language through digital and collaborative feedback techniques is a new course worked out by Cambridge University Press. The word feedback is mostly associated with teacher' measuring 
the class performance but it is also important for learners' perception of the progress they managed to achieve.

Cambridge Dictionary gives the following definition of feedback: an opinion from someone about something that you have done or made [Cambridge Dictionary, 2020]. The available free digital resources can make giving feedback far more practical, it can play a major role in helping students with their language learning efforts to understand how they are progressing. Artificial intelligence (AI) feedback gives students specific suggestions on how to adjust their production (spoken or written) in a more independent way. In the past few years, free AI tools became available and can be applied in the educational context. For illustrative purposes we can address the site forwriting skills development Write \& Improve [Write \& Improve, 2020]. It allows to get feedback on written letters and compositions, receive specific key hints on the printed works. Write \& Improve uses new technology developed at the University of Cambridge to mark English writing accurately. It shows the parts of inserted text that may need improvement, helps check students' spelling, grammar and vocabulary.

Similar service helps the learner get feedback on the intelligibility of their pronunciation. The voice typing in Google Docsis a practical alternative to feedback from a teacher. The students just press the microphone icon and read in real time as the system transcribes what was spoken. Students can then reflect on their pronunciation and practice the sounds that Google Docs struggles to understand and transcribe. Referring to an online dictionary is another way to learn theaccurate pronunciation of words. And it is a free tool that we can encourage our students to use.

These ideas all play a role in enabling our students to make good use of the available and free technical resources to study and improve, as education is more likely to be effective when feedback emphases features of the task (success criteria) and focuses learning goals.

A useful feedback can be also obtained while working with Digital Storieswhich are "multimedia movies that combine photographs, video, animation, sound, music, text, and often a narrative voice. Digital stories may be used as an expressive medium within the classroom to integrate subject matter with existent knowledge and skills from across the curriculum. Students can work individually or collaboratively to produce their own digital stories. Once completed, these stories can easily be uploaded to the Internet and can be made available to an international audience, depending on the topic and purpose of the project" [Henson, 2015, c. 103]. Students can publish their digital stories online and so share their results with an authentic audience. It opens access to feedback and learning through the works of others, including their peers. Digital storytelling suits students with different learning abilities and styles and strengthens cooperation among them.

Similar purposes can be achieved through the web-quest model, which is actively used in the educational process as one of the strategies for integrating the Internet. The authors define the web quest as "a type of reference-oriented activity of students using the Internet resources". [Volkova, 2018]. Due to the nature of the web-quest, the tasks can be set so as to resemble reality. This is at the core of the motivational aspect of the method. There many benefits of using web-quests during English classesas they:

- help educators to fit the Internet into the language classes as they do not involve exceptional technical background;

- are mostly team actions and inspire communication and distribution of information among group mates;

- function as a linguistic tool, but can also bear out interdisciplinary functions;

- enhance critical thinking skills and analyzing viewpoints;

- can be both thrilling and genuine tasks and encourage students to assess the activities they are involved in.

In essence, web-quests are small projects in realization of which the Internet serves as the main source of information. Web-quests can be teacher-made or learner-made; all depends on the education activity the instructor chooses. 
There are a number of useful and unique links to educational web quests such as:

- universal gamification tools for training;

- technology for creating educational Internet resources, for example, the Filamentality server (interactive website created to help you search the Internet and collect useful educational web resources);

- accumulation of web requests (information about web requests);

- specific examples of web quests;

- multimedia applications;

- a collection of necessary or desirable prerequisites for completing a web quest.

The above Internet services, resources and their brief characteristics are just some components of e-learning, which, as part of a holistic learning process, should help in formation of digital competence of all educational process participants as well as their readiness for selfdevelopment and lifelong education.

\section{Conclusion}

The mentioned above Internet services, techniques and methods are just a small fraction of useful electronic teaching means. We live in a digital age where technology is not an option and digital competence became a new reality of the innovative learning environment altering the way we deliver education. Higher education is already experiencing a period of unprecedented change worldwide. Realizing that it is a complex system, which involves multiple players and complicated processes, working in an innovative learning environment becomes a more robust, continuously improving cognitive practice where training is collaborative. As learning environment includes the physical, social, and pedagogical context in which instruction occurs, it supports strengths-based teaching and learning; offers school community flexibility, ubiquity, connectedness and feedback.

Historically, a gap has existed between the two worlds of formal and informal learning, theory and practice. The challenge is to break the barriers between these silos. Traditional learning has been formal, structured, intentionally planned, whereas innovative learning makes the classroom informal at nature and connects it with a real world via IT.

The results of our research have revealed the main benefits of digital competence in the frame of the innovative learning environment and allowed to find out the main sorts of skills and techniques teachers require:

- identifying the technological preferences of students, realizing the ways that students use and learn with web tools; values;

- encouraging students to choose and use web tools, reflect on and share their learning

- defining clear criteria to assess, evaluate, and introduce the learning affordances and benefits of web tools by students and teachers;

- selecting appropriate web tools to support different phases of teaching and learning processes; designing appropriate learning tasks;

- getting information of other teachers' practices and success stories.

Digital competence acquisition can improve the educational process not only by helping teachers to establish a student-centric learning environment, but also by supporting their professional development. In this regard, Kennedy [Ertmer, Ottenbreit-Leftwichcited, 2010] noted that the most important feature of a professional development approach is a strong focus on helping teachers understand how students learn specific content, and how specific instructional practices and tools can support student learning outcomes.

The study confirmed that implementation of digital technologies into university educational environment has a positive impact on students' engagement. The global digital society demands creating of an innovative learning environment that addresses the needs of our today's 
learners and is aimed at their inspiring. It is really a challenge to the teacher's success in the classroom and is not always an easy task. The learning environment should encourage the relationship among the educators and the students. Being a new concept of the innovative learning environment digital competence can greatly influence the dynamics of the lesson while rearranging a classroom by means of available technology and resources.

\section{Source list}

1. Cambridge Dictionary. Cambridge University Press. 2020. Available at: http: //www.dictionary.cambridge.org/dictionary/english-russian/feedback (accessed: 01.02.2020).

2. Mem Rise. Английские курсы. 2010-2020. Available at: http://www.memrise.com/courses /english/english/ (accessed: 10.02.2020).

3. Progress of goal 4 in 2019. Department of Economic and Social Affairs. Sustainable Development 2020. Available at: https://sdgs.un.org/goals/goal4 (accessed 10.12.2019).

4. Recommendation of the European Parliament and of the Council of 18 December 2006 on key competences for lifelong learning. 2006. Available at: http://www.eur-lex.europa.eu/legalcontent/EN/TXT/?uri=celex\%3A32006H0962 (accessed: 05.11.2019).

5. Royal Society (Great Britain). 2012. Shut down or restart? The way forward for computing in UK schools. London, The Royal Society, Education Section, 121 p.

6. South Korean Elementary School Teachers' Perceptions Of Professional Curricular Autonomy. 2017. Available at: www.scholarworks.iu.edu/dspace/bitstream/handle/2022 /21611/Min\%20 Dissertation.pdf?sequence $=1$ (accessed 28.10.2019).

7. The Digital Competence Framework 2.0. An official website of the European Union. 2019. Available at: https://ec.europa.eu/jrc/en/digcomp/digital-competence-framework (accessed: 05.02.2020)

8. Webquests. 2020. Available at: http://www.teachingenglish.org.uk/article/webquests (accessed: 01.02.2020).

9. Write \& Improve. Cambridge English. 2020. Available at: https://www.cambridgeenglish.org /learning-english/free-resources/write-and-improve/ (accessed: 01.02.2020).

\section{References}

1. Bazanova E.M. 2012. Razvitie u studentov magistratury umeniy samostoyatel'no izuchat' inostrannyy yazyk na baze mul'timediynykh tekhnologiy [Development of master's students' skills to independently study a foreign language based on multimedia technologies]. Vestnik of Moscow State Linguistic University. Release Modernizatsiya sistemy podgotovki po inostrannomu yazyku v neyazykovykh vuzakh. Pedagogicheskie nauki [Modernizing the system of foreign language teaching and learning at non-linguistic institutions of higher learning. Pedagogic studies], 645: 161-169.

2. Boldova T.A. 2012. Formirovanie i razvitie umeniy studentov obshchat'sya v Internete na inostrannom yazyke [Formation and development of students' skills to communicate on the Internet in a foreign language]. Vestnik of Moscow State Linguistic University. Release Modernizatsiya sistemy podgotovki po inostrannomu yazyku v neyazykovykh vuzakh. Pedagogicheskie nauki [Modernizing the system of foreign language teaching and learning at non-linguistic institutions of higher learning. Pedagogic studies], 645: 170-175.

3. Volkova O.V. 2018. Kvestovaya model' obucheniya inostrannomu yazyku [Quest model of teaching a foreign language]. In: Pedagogika v sovremennoy sisteme vysshey shkoly [Pedagogy in the modern system of higher education]. Materialy Mezhdunarodnoy nauchno-prakticheskoy konferentsii, Belgorod, 27-28 marta 2018 goda. Belgorod, Publ. Izdatel'stvo BUKEP: 45-51.

4. Davidenko E.S. 2013. Ispol'zovanie informatsionnykh kart dlya podgotovki studentov $\mathrm{k}$ inoyazychnomu professional'nomu obshcheniyu [Using information cards to prepare students for foreign language professional communication]. Vestnik of Moscow State Linguistic University. Release Inostrannyy yazyk kak komponent professional'noy podgotovki v neyazykovom vuze. Pedagogicheskie nauki [Foreign language as a component of vocational training at a non-language institution for higher professional education. Pedagogic studies], 12 (672): 124-132. 
5. Irkhina I.V., Shirokova M.V., Besedina O.A. 2012. Opyt organizatsii pedagogicheskogo soprovozhdeniya distantsionnogo obucheniya studentov v protsesse izucheniya distsipliny «Inostrannyy yazyk» v NIU «BelGU» [Experience in organizing pedagogical support of distance learning for students in the process of studying the discipline "Foreign language" at the National Research University "BelSU"]. Tomsk State Pedagogical University Bulletin, 2 (117): 72-75.

6. Isaev I.F., Eroshenkova E.I. 2011. Professional'no-tsennostnaya ustanovka budushchego spetsialista: ot sushchnosti k tekhnologii formirovaniya [Professional value attitude of a future specialist: from essence to technology of formation]. The Siberian Pedagogical Journal, 3: 44-53.

7. Kozhevnikova T.V. 2011. Sovremennye tendentsii razvitiya distantsionnogo obucheniya inostrannomu yazyku (otechestvennyy i zarubezhnyy opyt) [Modern trends in the development of distance learning a foreign language (domestic and foreign experience)]. Vestnik of Moscow State Linguistic University. Release Inostrannyy yazyk kak komponent professional'noy podgotovki $\mathrm{v}$ neyazykovom vuze. Pedagogicheskie nauki [Priorities in foreign language teaching. Pedagogical studies], 618: $142-152$.

8. Kozhevnikova T.V. 2014. Razvitie umeniy professional'no orientirovannogo onlayn-chteniya $\mathrm{v}$ neyazykovom vuze [Development of skills for professionally oriented online reading in a non-linguistic university]. Vestnik of Moscow State Linguistic University. Release Inostrannyy yazyk kak komponent professional'noy podgotovki v neyazykovom vuze. Pedagogicheskie nauki [Scientific fundamentals of foreign language teaching innovative system in higher non-language educational institutions. Pedagogical studies], 12 (698): 141-148.

9. Kolos N.V., Kuz'minova Yu.V. 2016. Mobil'nost' innovatsionnykh resheniy $v$ sfere informatsionnykh tekhnologiy i elektronnoy kommertsii [Mobility of innovative solutions in the field of information technology and ecommerce]. Herald of the Belgorod University of Cooperation, Economics and Law, 1 (57): 140-148.

10. Lysova I.I., Vitokhina O.A., Skripchenko P.V., Roslyakova E.F. 2016. Ekonomika yazyka kak resurs ustoychivogo razvitiya [Language economy as a resource for sustainable development]. Herald of the Belgorod University of Cooperation, Economics and Law, 1 (57): 126-139.

11. Rastova L.M., Lopatkin V.M., Matveeva N.A. et al. 2006. Pedagogicheskie kadry - osnova innovatsionnogo razvitiya obrazovaniya [Teaching staff - the basis of innovative development of education]. Ed. L.M. Rastovoy. Barnaul, Publ. Izdatel'stvo Barnaul'skogo gosudarstvennogo pedagogicheskogo universiteta, $252 \mathrm{p}$.

12. Rozdol'skaya I.V., Vistorobskaya E.N., Grebenik L.G. 2017. Ispol'zovanie resursov HRanalitiki i Digital-tekhnologiy $\mathrm{v}$ usloviyakh perekhoda $\mathrm{k}$ setevoy tsifrovoy ekonomike [Using the resources of HR analytics and digital technologies in the transition to a networked digital economy]. Herald of the Belgorod University of Cooperation, Economics and Law, 5 (66): 129-140.

13. Tarasova E.E., Altonayan A., Lysova I.I. 2017. Razvitie kriticheskogo myshleniya kak faktor formirovaniya nauchnogo znaniya i predprinimatel'skikh kompetentsiy [Development of critical thinking as a factor in the formation of scientific knowledge and entrepreneurial competencies]. Herald of the Belgorod University of Cooperation, Economics and Law, 5 (66): 9-27.

14. Benavides F., Dumont H., Istance D. (Eds.). 2010. Nature of Learning: Using Research to Inspire Practice. OECD. 12 p.

15. Ertmer P.A., Ottenbreit-Leftwich A.T. 2010. Teacher Technology Change. Journal of Research on Technology in Education, 42 (3), 255-284. DOI: https://doi.org/10.1080 /15391523.2010.10782551.

16. Freire P. 1985. Reading the World and Reading the Word: An Interview with Paulo Freire. In: Making Meaning, Learning Language. Language Arts, 62 (1): 15-21. Available at: http://www.jstor.org/stable/41405241 (accessed: 11.01.2020).

17. Henson K.T. 2015. Curriculum planning. Integrated Multiculturalism, Constructivism, and Education Reform. Waveland Press, Inc, 502 p.

18. Neumann K., 2018. Digital economy: for the benefit of users, business and the state. In: Bussiness Excellence, Brussel, European Commission: 22-29. 


\section{Список литературы}

1. Базанова Е.М. 2012. Развитие у студентов магистратуры умений самостоятельно изучать иностранный язык на базе мультимедийных технологий. Вестник Московского государственного лингвистического университета. Выпуск: Модернизация системы подготовки по иностранному языку в неязыковых вузах. Педагогические науки, 645: 161-169.

2. Болдова Т. А. 2012. Формирование и развитие умений студентов общаться в Интернете на иностранном языке. Вестник Московского государственного лингвистического университета. Выпуск: Модернизация системы подготовки по иностранному языку в неязыковых вузах. Педагогические науки, 645: 170-175.

3. Волкова О.В. 2018. Квестовая модель обучения иностранному языку. В кн.: Педагогика в современной системе высшей школы. Материалы Международной научно-практической конференции, Белгород, 27-28 марта 2018 года. Белгород, Издательство БУКЭП: 45-51.

4. Давиденко Е.С. 2013. Использование информационных карт для подготовки студентов к иноязычному профессиональному общению. Вестник Московского государственного лингвистического университета. Выпуск: Иностранный язык как компонент профессиональной подготовки в неязыковом вузе. Педагогические науки, 12 (672): 124-132.

5. Ирхина И.В., Широкова М.В., Беседина О.А. 2012. Опыт организации педагогического сопровождения дистанционного обучения студентов в процессе изучения дисциплины «Иностранный язык» в НИУ «БелГУ». Вестник Томского государственного педагогического университета, 2 (117): 72-75.

6. Исаев И.Ф., Ерошенкова Е.И. 2011. Профессионально-ценностная установка будущего специалиста: от сущности к технологии формирования. Сибирский педагогический журнал, 3: 44-53.

7. Кожевникова Т.В. 2011. Современные тенденции развития дистанционного обучения иностранному языку (отечественный и зарубежный опыт). Вестник Московского государственного лингвистического университета. Выпуск: Приоритетные направления в обучении иностранным языкам. Педагогические науки, 618: 142-152.

8. Кожевникова Т.В. 2014. Развитие умений профессионально ориентированного онлайнчтения в неязыковом вузе. Вестник Московского государственного лингвистического университета. Выпуск: Научно-методические основы формирования инновационной системы языковой подготовки в неязыковом вузе. Педагогические науки, 12 (698): 141-148.

9. Колос Н.В., Кузьминова Ю.В. 2016. Мобильность инновационных решений в сфере информационных технологий и электронной коммерции. Вестник Белгородского университета кооперации, экономики и права, 1 (57): 140-148.

10. Лысова И.И., Витохина О.А., Скрипченко П.В., Рослякова Е.Ф. 2016. Экономика языка как ресурс устойчивого развития. Вестник Белгородского университета кооперации, экономики и права: 1 (57): 126-139.

11. Растова Л.М., Лопаткин В.М., Матвеева Н.А. и др. 2006. Педагогические кадры основа инновационного развития образования. Под ред. Л.М. Растовой. Барнаул, Издательство Барнаульского государственного педагогического университета, $252 \mathrm{c}$.

12. Роздольская И.В., Висторобская Е.Н., Гребеник Л.Г. 2017. Использование ресурсов HR-аналитики и Digital-технологий в условиях перехода к сетевой цифровой экономике. Вестник Белгородского университета кооперации, экономики и права, 5 (66): 129-140.

13. Тарасова Е.Е., Алтонаян А., Лысова И.И. 2017. Развитие критического мышления как фактор формирования научного знания и предпринимательских компетенций. Вестник Белгородского университета кооперации, экономики и права, 5 (66): 9-27.

14. Benavides F., Dumont H., Istance D. (Eds.). 2010. Nature of Learning: Using Research to Inspire Practice. OECD. 12 p.

15. Ertmer P.A., Ottenbreit-Leftwich A.T. 2010. Teacher Technology Change. Journal of Research on Technology in Education, 42 (3), 255-284. DOI: 10.1080 /15391523.2010.10782551 
16. Freire P. 1985. Reading the World and Reading the Word: An Interview with Paulo Freire. In: Making Meaning, Learning Language. Language Arts, 62 (1): 15-21. Available at: http://www.jstor.org/stable/41405241 (accessed: 11.01.2020).

17. Henson K.T. 2015. Curriculum planning. Integrated Multiculturalism, Constructivism, and Education Reform. Waveland Press, Inc, 502 p.

18. Neumann K. 2018. Digital economy: for the benefit of users, business and the state. In: Bussiness Excellence, Brussel, European Commission: 22-29.

\section{ИНФОРМАЦИЯ ОБ АВТОРАХ}

Лысова Ирина Ивановна, кандидат педагогических наук, доцент, заведующая кафедрой иностранных языков Белгородского университета кооперации, экономики и права, г. Белгород, Россия

Витохина Ольга Алексеевна, кандидат педагогических наук, доцент кафедры иностранных языков Белгородского университета кооперации, экономики и права, г. Белгород, Россия

Волкова Ольга Владимировна, кандидат педагогических наук, доцент кафедры иностранных языков Белгородского университета кооперации, экономики и права, г. Белгород, Россия

\section{INFORMATION ABOUT THE AUTHORS}

Irina I. Lysova, Candidate of Pedagogical Sciences, Associate Professor, Head of the Chair of Foreign Languages, Belgorod University of Cooperation, Economics and Law, Belgorod, Russia

Olga A. Vitokhina, Candidate of Pedagogical Sciences, Associate Professor, Chair of Foreign Languages, Belgorod University of Cooperation, Economics and Law, Belgorod, Russia

Olga V. Volkova, Candidate of Pedagogical Sciences, Associate Professor, Chair of Foreign Languages, Belgorod University of Cooperation, Economics and Law, Belgorod, Russia 